\title{
KARAKTER DISIPLIN ANAK DALAM PEMBELAJARAN MENGGAMBAR
}

\author{
Farida Mayar \\ Dosen Pendidikan Guru Pendidikan Anak Usia Dini \\ Fakultas Ilmu Pendidikan \\ Universitas Negeri Padang \\ Email: mayarfarida@gmail.com
}

\begin{abstract}
Abstrak
Karakter disiplin anak dalam pembelajaran menggambar bertujuan untuk mengetahui disiplin anak dalam pembelajaran menggambar di Taman Kanakkanak (TK). Jenis penelitian kualitatif mengunakan observasi, wawancara. Perekaman, dan pemotretan. Hal ini dilakukan untuk mengkaji data informasi yang berhubungan erat dengan karakter disiplin kegiatan pembelajaran menggambar, dan hasil menggambar anak.

Hasil penelitian dapat diketahui Guru membelajarkan anak tentang karakter disiplin dimulai nilai-nilai agama, dengan dari tema diri sendiri, seluruh panca indra diceritakan kepada anak seperti panca indra dikerjakan sesuai dengan ketentuan agama seperti dimulai tangan kanan untuk mengerjakan yang baik seperti anak membagi-bagikan buku gambar kepada temannya, berarti disini guru mengajarkan anak tentang disiplin melalui tangan kanan. Selanjutnya dalam menggambar anak tidak meniru gambar temannya, dari semua hasil gambar yang dibuat anak berbeda-beda, sesuai dengan ide, gagasan dan imajinasi anak masingmasing. Tentang hasil gambar mengarsil krayon warna tidak keluar dari garis, hasil gambar bersih, dan rapi. Selanjut anak tampil ke depan kelas untuk meceritakan hasil gambarnya, diakhiri dengan ibu guru bercerita tentang tingkahlaku anak selama proses pembelajaran berlangsung guna untuk mengevaluasi disiplin selama pembelajaran menggambar berlangsung hal hasil anak disiplin semuanya.
\end{abstract}

\section{Kata Kunci: Karakter, Disiplin, Menggambar}

\section{Pendahuluan}

Mendidik sesuai potensi yang dimiliki sangat penting. Sebab kesesuaian dalam mendidik anak mempengaruhi perkembangan dimasa yang akan datang. Prinsip pembelajaran bermain sambil belajar seraya belajar sambil bermain, yang digunakan pendidikan terhadap anak didik dalam pengembangan seni budaya dan karakter bangsa mengusahakan agar anak didik mengenal dan menerima nilai-nilai seni budaya dan karakter bangsa sebagai milik bersama. Anak Taman kanak-kanak (TK) pada 
umumnya belum mengetahui apa yang baik dan buruk bagi mereka. Oleh karena itu, pendidik perlu mencontoh dan membimbing kearah yang baik seperti pendidikan karakter.

Puskur dalam Suryanto (2011) menyatakan bahwa karakter teridentifikasi 18 nilai yang bersumber dari agama, pancasila, budaya, dan tujuan pendidikan nasional yaitu religius, jujur, toleransi, disiplin, kerja keras, kreatif, mandiri, demokrasi, rasa ingin tahu, semangat, kebangsaan, cinta tanah air, menghargai prestasi, bersahabat/komunikatif, cinta damai, gemar membaca, peduli lingkungan, peduli sosial, dan tanggung jawab.

Anak TK diibaratkan bagaikan kecambah yang akan cepat berkembang, sehingga di TK merupakan masa emas, setiap anak merupakan peletakan batu pertama dasar-dasar pendidikan, supaya anak TK optimal menyerap ilmu pengetahuan. Karakter anak TK dalam kegiatan dan hasil gambar yang dibuatnya sesuai dengan apa yang diungkapkannya.

Setiap anak didik dalam menggambar pada umumnya mencurahkan apa yang ada dalam lubuk hati diungkapkan melalui kertas, hal ini tentunya tampaklah karakter pribadi anak didik. Karakter dalam menggambar tidak perlu dicari-cari, karena karakter tersebut akan lahir sendiri, dan akan tumbuh dengan sendirinya. Gil (1996) keindahan dalam seni mempunyai hubungan erat dengan kemampuan manusia dalam berekspresi dan menilai karya seni yang bersangkutan atau terkait dengan pola pandang dan pengalaman individu dalam berkreativitas.

Purwanto (1997) menyatakan bahwa karakter adalah struktur batin manusia yang tampak pada kelakuan dan perbuatan yang merupakan ciri khas pribadi yang bersangkutan. Jung (2003) setiap tipe kepribadian manusia menonjolkan suatu proses karakter atau ciri khasnya yang mempengaruhi secara luas perilaku-perilaku manusia. Dalam pola itu ia mengatakan bahwa manusia memiliki dua orientasi atau kecenderungan dasar dalam menyalurkan perhatian dan seluruh kemampuannya. Kecenderungan mengarahkan dan menyalurkan perhatian keluar disebut extrovert. Sebaliknya kecenderungan untuk mengarahkan dan menyalurkan perhatian ke dalam diri sendiri disebut introvert.

Pembentukan karakter dan watak atau kepribadian sangat penting (Suryanto 2011). Dalam pada itu, Puskur dalam Suryanto (2011) menyatakan 
bahwa karakter teridentifikasi 18 nilai yang bersumber dari agama, pancasila, budaya, dan tujuan pendidikan nasional yaitu religius, jujur, toleransi, disiplin, kerja keras, kreatif, mandiri, demokrasi, rasa ingin tahu, semangat, kebangsaan, cinta tanah air, menghargai prestasi, bersahabat/komunikatif, cinta damai, gemar membaca, peduli lingkungan, peduli sosial, dan tanggung jawab.

Samani (2012) karakter adalah nilai dasar yang membangun pribadi seseorang, terbentuk baik karena pengaruh hereditas maupun pengaruh lingkungan yang membedakan dengan orang lain, serta diwujudkan dalam sikap dan prilakunya dalam kehidupan sehari-hari. Daryusti (2011) menyatakan mengkaji karakter sesuatu tidak dapat dipisahkan dari norma estetis yang terdapat dalam perwujudannya. Kostelametz (1978) mengatakan bahwa estetika adalah kata lain dari filsafat seni, yaitu pikiran abstrak yang memberikan pengertian terhadap pengalaman artistik secara umum untuk mendapatkan relevansi komprehensif. Terkait dengan hal itu, Read (1990) mengatakan bahwa keindahan dapat didefinisikan sebagai sesuatu yang menyenangkan. Disisi lain, Gil (1976) menyatakan bahwa keindahan dalam seni mempunyai hubungan erat dengan kemampuan manusia dalam menilai karya seni yang bersangkutan untuk menghargai keindahan. Maka dari itu perlu disadari bahwa suatu keindahan tidak akan terlepas atau sangat terkait dengan pola pandang religius dari seseorang karena kehidupan kesenian dengan keagamaan seolah-olah memiliki kesinambungan perwujudan karya seni. Keterkaitan ini tampak pada aktivitas yang muncul dalam penghayatan karya seni yang selaras dengan keagamaan yang terjalin menjadi satu kesatuan yang harmonis.

Dari penjelasan di atas maka hubungan karakteriatik dengan seni sangat erat yaitu dengan adanya karakter akan tercipta karya seni yang indah yang mencerminan budaya bangsa. Dalam delapan belas karakter dalam pendidikan salah satunya yang diungkapkan adalah disiplin, karena disiplin merupakan hal sangat penting dalam kehidupan sehari-hari, khususnya dalam pendidikan menggambar.

Di antara ajaran mulia yang sangat ditekankan dalam Islam adalah disiplin. seperti mengerjakan shalat lima kali sehari semalam dengan tepat waktu. Disiplin merupakan salah satu pintu meraih kesuksesan. Kepakaran dalam bidang ilmu 
pengetahuan tidak akan memiliki makna signifikan tanpa disertai sikap disiplin. Sering kita jumpai orang berilmu tinggi tetapi tidak mampu berbuat banyak dengan ilmunya, karena kurang disiplin.

Sebaliknya, banyak orang yang tingkat ilmunya biasa-biasa saja tetapi justru mencapai kesuksesan luar biasa, karena sangat disiplin dalam hidupnya diibaratkan agama tanpa ilmu buta, ilmu tanpa agama lumpuh. Analoginya sederhana, kita bisa perhatikan pentingnya peraturan itu dalam menggambar anak diajarkan supaya dalam menggambar mewarnai tidak boleh keluar garis. Kemudian mengembalikan bahan dan alat menggambar diletakan pada tempatnya semula. Contoh di atas tentu bisa ditarik ke dalam ranah kehidupan yang lebih luas. Tegasnya, disiplin sangat ditekankan dalam urusan dunia, dan lebih-lebih urusan akhirat. Tidak heran jika Allah memerintahkan kaum beriman untuk membiasakan disiplin. Perintah itu, antara lain, tersirat dalam Al-Qur'an suratAlJumuah,ayat9-10.

Tidak ada lembaga pendidikan yang tidak mengajarkan disiplin kepada anak didiknya. Demikian pula organisasi atau institusi apapun, lebih-lebih militer, pasti sangat menekankan disiplin kepada setiap pihak yang terlibat di dalamnya. Semua pasti sepakat, rencana sehebat apapun akan gagal di tengah jalan ketika tidak ditunjang dengan disiplin. Menurut Kamus Besar Bahasa Indonesia (KBBI), disiplin adalah ketaatan atau kepatuhan terhadap peraturan. Ketaatan berarti kesediaan hati secara tulus untuk menepati setiap peraturan yang sudah dibuat dan disepakati bersama. Orang hidup memang bukan untuk peraturan, tetapi setiap orang pasti membutuhkan peraturan untuk memudahkan urusan hidupnya.

Dewasa ini, sikap disiplin mulai ditinggalkan oleh sebagian masyarakat kita. Mereka menganggap disiplin hanyalah sebuah wacana belaka tanpa mereka jalankan. Disiplin sama halnya dengan patuh terhadap tata tertib/peraturan. Di Indonesia banyak orang Indonesia yang tidak taat pada peraturan/tata tertib yang mereka buat sendiri misalkan adanya peraturan-peraturan di sekolah tapi masih banyak dilanggar, trotoar yang dijadikan tempat usaha penjual kaki lima, PNS yang pulang kerja belum pada waktunya, di dalam masyarakat tentu ada aturan 
normanya, walaupun aturan itu baik tertulis maupun tidak tertulis dan lain sebagainya.

Pada dasarnya setiap aturan itu bersifat mengikat dan mempunyai tujuan yang ingin dicapai dalam anggota di dalamnya. Ketika ada anggota di dalamnya menaati peraturan tersebut, maka ia bisa disebut telah melaksanakan sikap disiplin tersebut dan apabila berbuat sebaliknya akan mendapat sanksi. Sebenarnya untuk bersikap disiplin itu mudah apabila kita lakukan secara bertahap akan berubah menjadi kebiasaan.

Dari kebiasaan tersebut akan memicu kita bersikap sesuai dengan peraturan yang ada. Namun, saat ini masyarakat kita sekarang membiasakan kebiasaan yang berlawanan dari sikap disiplin. Masyarakat kita seolah apatis terhadap sikap disiplin yang sebenarnya mereka tahu apa itu makna disiplin. Mereka menganggap sikapnya yang jauh dari kata/makna disiplin adalah sesuatu yang wajar dan bisa dimaklumi.

Hal demikianlah yang menjadikan kinerja masyarakat kita tidak maksimal dan juga menimbulkan berbagai masalah lainnya. Membudayakan sikap disiplin dalam masyarakat dewasa ini sangatlah penting untuk menjadikan tatanan kehidupan masyarakat yang baik. Adapun beberapa cara untuk menumbuhkan budaya disiplin dalam masyarakat antara lain merubah pola pikir masyarakat tentang kedisiplinan, penanaman sikap disiplin sejak dini. Adanya sanksi tegas bagi pelanggar, sosialisasi-sosialisasi tentang makna disiplin maupun sebagainya.

Disiplin adalah suatu proses belajar mengembangkan kebiasaan-kebiasaan, penguasaan diri dan mengaku tanggung jawab pribadinya terhadap masyarakat dan peraturan yang ada, maka cobalah untuk bersikap disiplin karena disiplin adalah tanggung jawab kita.

Dalam paparan di atas maka perlu disiplin sejak anak usia dini terlebih dalam kegiatan menggambar. Anak usia dini merupakan masa keemasan (golden age) bagi anak. Masa keemasan (golden age) ini mempunyai arti penting dan berharga karena masa ini merupakan pondasi bagi masa depan anak. Masa ini anak memiliki kebebasan untuk berekspresi tanpa adanya suatu aturan yang menghalangi dan membatasinya. Oleh karena itu, di masa keemasan (golden age) 
ini perlu bagi orangtua, guru, dan masyarakat untuk memberikan penanaman kedisipilinan kepada anak agar anak dapat menerapkan disiplin sejak dini yang akan mempengaruhi kedisiplinan anak pada masa dewasanya nanti.

Poerwadarminta dalam Kamus Besar Bahasa Indonesia (2005: 28) mengartikan kata disiplin adalah latihan batin dan watak dengan maksud supaya segala perhatian anak selalu mentaati tata tertib di sekolah. Sedangkan menurut Hurlock (2001) dalam bukunya Perkembangan Anak mengartikan perilaku disiplin yakni perilaku seseorang yang belajar dari atau secara sukarela mengikuti seorang pemimipin. Dalam hal ini anak merupakan murid yang belajar dari orang dewasa tentang hidup menuju kearah kehidupan yang berguna dan bahagia dimasa mendatang.

Dari pengertian-pengertian di atas dapat disimpulkan bahwa disiplin adalah tata tertib atau peraturan yang harus dilakukan dalam kehidupan sehari-hari untuk melatih watak anggota yang ada dalam lembaga kependidikan. Pokok utama dari disiplin adalah peraturan. Disiplin pada kegiatan menggambar seperti anak duduk dengan tertib medengarkan cerita guru tentang tema, langkah-langkah menggambar, gambar yang akan dibuat anak, bahan alat yang akan diambil anak, sewaktu menggambar, selesai menggambar mereka membereskan bahan dan alat dan merapikan kembali seperti semula

\section{Metode Penelitian}

Penelitian ini mengunakan metode kualitatif yang bersifat deskriptif analisis. Populasi penelitian adalah Taman Kanak-kanak dan sampel kelompok B. Untuk menemukan karakter disiplin dalam kegiatan gambar yang telah dibuat anak didik. Mulyasa (2004) penelitian kualitatif bertujuan untuk memperoleh pengalaman yang ditentukan mengenai pengalaman orang-orang sebagaimana dirasakan orang yang bersangkutan. Penelitian ini dilakukan melalui tiga tahap kegiatan, yaitu. (1) kegiatan awal, (2) kegiatan inti, dan (3) kegiatan penutup. Setelah dilakukan ke tiga tahap tersebut, peniliti mengkaji hasil gambar yang dibuat anak didik untuk mengungkap karakter gambar. Penelitian ini mengunakan informan yang terkait dengan kompetensi untuk dapat memberikan pendapat, pemikiran, penilaian dan penguatan-penguatan yang 
peneliti perlakuan dalam rangka penyusunan penyempurnaan dan memvalidasi penelitian ini.

Teknik dan alat pengumpulan data yang digunakan dalam penelitian ini mengunakan wawancara, observasi, perekaman, dan pemotretan. Hal ini dilakukan untuk merekam data informasi yang berhubungan karakter displin dalam kegiatan menggambar yang dilakukan anak Taman Kanak-kanak. Standar keabsahan dari pemikiran Guba (1989), yaitu: 1) Kepercayaan (credibility), 2) teralihan (transforability), 3) dapat dipertangung jawaban (dependability), dan 4)) penegasan atau kepastian (confirmability).

\section{Hasil dan Pembahasan}

Pembahasan hasil penelitian dilakukan dengan mengsingkronkan hasil penelitian dengan konsep dan teori-teori yang telah dikemukakan. Menurut Bogdan dan Biklen (1982) mengatakan tema adalah konsep atau teori yang timbul dari hasil penelitian. Hasil penelitian interprestasi data diformulasikan ke dalam bentuk tema dan topik penelitian.

Pada kegiatan awal gambar kita bisa melihat anak kedisiplinan karakter regelius kecintaan Tuhan Yang Maha Esa. Untuk nilai-nilai karakter kecintaan kepada Tuhan Yang Maha Esa guru TK telah melaksanakanya mulai datang ke TK anak bersalaman sama ibu guru dengan mengucapkan assamualuaikum, kemudian dilanjutkan pada upacara pagi, masuk kelas, begitu juga membaca ayatayat pendek. Pada kgiatan inti juga anak membaca bismilahhirahmanirrahhim sebelum bekerja dan dijelaskan tentang kekuasaan Tuhan Yang Maha Esa, seperti diri sediri. Ibu guru bercerita dan bertanya jawab siapa yang menciptakan kita, terlihat beberapa anak angkat tangan dari banyaknya anak angkat tangan guru memilih satu diantara mereka sedangkan teman yang lain tidak ada meribut dan merasa iri hati, temannya menjawab "Allah" semuanya disiplin mendengarkan jawaban dari temannya setelah itu guru dan anak tepuk tangan dengan gembira. dilanjutkan guru mulai bercerita tentang tema, untuk kegiatan menggambar anak mendengar dengan disiplin memperhatikan penjelasan dari guru, guru memuji disiplin dan tatatertib anaknya dengan bertepuk tangan semuanya. Selanjutnya 
guru menjelaskan tentang menggambar, anak mengambil buku gambar diloker tidak ada yang berebutan guru mengajarkan anak yaitu menunjuk tiga orang anak mengambil buku gambar kedepan dan membagikan buku gambar kepada temantemannya dengan senang menerima buku gambar, begitulah cara guru membagikan buku gambar tidak berebutan hal hasil ini menjaga supaya anak tidak ribut saat mengambil buku gambar. Begitu pula dengan krayon ada di loker anak TK menunjuk diantara mereka tiga orang untuk membagikan krayon untuk teman mereka dengan tertib sehingga disiplin tetap terjaga. Makna yang diambil dari disiplin adalah guru mengajarkan anak dengan cara ada jiwa sosial berbagi tugas untuk bersosialisasi pada temannya. Guru sebagai pendidik anak usia dini menanamkan nilai moral dan agama sesuai dengan pendapat Mahyuddin (2011) menyatakan Mendidik anak-anak disiplin dari kecil supaya mengikuti seruan Allah SWT dan meninggalkan segala larangannya, mendidik anak-anak dari kecil berakhlak mulia.

Seperti anak menggambil bahan dan alat untuk menggambar di atur sedemikian rupa lokernya masing-masing dengan tidak antrian mengambil buku gambar karena sudah diutus untuk membagikan buku gambar kepada teman mereka dengan disiplin dan sehingga tidak bergelut lalu teman yang diutus tadi pergi ketempat duduk teman yang telah disediakan. Pada saat mereka menggambar anak TK tidak meniru gambar temannya, mereka membuat sendirisendiri sesuai dengan ide dan gagasan, imajinasi dan kreativitasnya masingmasing. Dari paparan di atas bahwa anak telah melaksanakan karakter disiplin, memanfaatkan waktu untuk menggambar dilaksanakan oleh anak sesuai dengan ketentuan yang berlaku.

Gambar yang dibuat anak sesauai dengan kebebasannya yang menjadi disiplin, pada hal ini adalah anak membuat gambar dengan ide mereka masingmasing seperti ada anak membuat gambar tangan diri sendiri kemudian diberi hiasan sebuah cincin yang melekat pada jari manis dengan garis spontan, dan lainlain. Peneliti memberi penghargaan kepada anak tersebut bahwa gambarnya bagus. Peneliti mewawancari anak ini kenapa gambar tangan yang dibuat. Anak ini menjawab bahwa kata ibu guru tangan adalah ciptaan Tuhan berguna untuk 
mengerjakan pekerjaan yang baik-baik saja, seperti untuk menulis, makan dan berdoa, dan saya datang ke sekolah selalu disambut dengan bersalam juga dengan tangan ibu guru harum lagi. Ada anak yang membuat gambar bungga, gambar sampah, banjir, dan sebagainya. Dalam hal ini, peneliti terharu mendengar percakapan dari anak bahwa dia telah tahu bahwa Tuhan menciptakan tangan manusia patut kita hargai sewaktu itu peneliti mengancungkan jari jempol sambil memuji gambanya bagus, terlihat diwajahnya merasa gembira. Jadi gambar yang dibuat anak semuanya bukanlah contekan dari gambar temmannya melainkan adalah ciptaan dia sendiri, berarti disini anak telah melaksanakan disiplin terhadap dirinya. Makna yang diambil dari anak adalah dari kecil sudah dibiasakan disiplin sudah besar menjadi biasa hal inilah perlu kita kembangkan demi masa depan bangsa. Keberhasilan pendidikan, tergantung pada pendidik usia dini. Sebelum masuk sekolah dasar anak harus diberi pendidikan yang tepat dan disiplin, maksudnya pengaruh yang sesuai dengan perkembangannya (Santoso, 2011).

Pada kegiatan akhir proses pembelajaran ditutup dengan memberikan apsresiasi kepada anak yang artinya mulai dari merangkum disiplin anak dalam kegiatan belajar menggambar sampai kepada hasil gambar anak. Seperti pada kedisiplin anak dalam kegiatan belajar menggambar guru memuji semua anak sikap tingkahlakunnya dari mulai dia mendengar dari cerita guru, dengan tema bebek yang disiplin, yang intinya bebek pada pagi hari pergi mencari makan bersama dengan keteraturan berjalan selalu satu berbaris memanjang tidak ada yang duluan dan tidak berebutan dalam perjalannya menuju sawah, sore harinya bebek pulang pun begitu juga selalu teratur, terlihat semuanya bebek sangat disiplin dalam melakukan pekerjaan dia selalu bermain diair tidak mengangu manusia. Dari paparan di atas guru mencontohkan bahwa binatang saja hidupnya disiplin. Bagaimana dengan anak ibu. Nah tadi ibu lihat anak ibu disiplin semuanya tidak yang bertengkar baik semua. Mari kita tepuk tangan semuanya, mengambil buku gambar dan krayon anak ibu terttib mengambilnya dengan diutus tiga orang yang membagikan buku gambar kepada teman semua semuanya berjalan dengan tertib, tentang gambar yang dibuat anak, gambar yang dibuat 
anak sesuai dengan ide dan gagasan masing-masing tidak ada yang sama. semuanya berjalan tertib dan disiplin.

\section{Kesimpulan}

Berdasarkan hasil penelitian dan pembahasan dapat dikemukakan beberapa hal berkaitan dengan karakter disiplin anak dalam gambar pada Taman Kanak-kanak.

Guru membelajarkan anak karakter disiplin dimulai nilai-nilai agama, dengan dimulai dari tema diri sendiri, seluruh panca indra diceritakan kepada anak. Selanjutnya panca indra dikerjakan sesuai dengan ketentuan agama seperti dimulai tangan kanan untuk mengerjakan yang baik seperti anak membagibagikan buku gambar kepada temannya. berarti disini guru mengajarkan anak tentang disiplin melalui tangan, kemudian dalam menggambar anak tidak meniru gambar temannya, dari semua hasil gambar yang dibuat anak berbeda-beda, sesuai dengan ide, gagsan dan imajinasi anak. Mengarsil krayon warna tidak keluar dari garis, hasil gambar bersih, kemudian anak tampil ke depan untuk meceritakan hasil gambarnya, diakhiri dengan ibu guru bercerita tentang tingkahlaku anak selama proses pembelajaran berlangsung menanamkan disiplin juga kepada anak hal hasil disiplin semuanya.

\section{Daftar Rujukan}

Al-Qur'an Surat Al-Jumuah, ayat 9-10. Bandung: CV Dipenogoro

Bogdan, R.C, Biklen, SK. 1982. Qualitative Research for Education: An Introduction to Theory Methods Thind edition. Boston: Allyn and Bacon Charmaz.

Daryusti. 2011. Hegemoni Penghulu Dalam Perpektif Budaya (Edisi Revisi) Yogyakarta: Cipta Media.

Gil. 2011. Sejemput Keindahan Dalam Seni. Jakarta: Varia

Guba, E.G. \& Lincoln, Y. S. 1989. Fourt Generation Evaluation. Newbury Park, Ca: Sage.

Hurlock, B Elizabeth. 2001. Perkembangan Anak. Jilid 1. Jakarta: Erlangga.

Kostelamet. Z. Richard (ed) 1978. Estethics Contenporary, New York: Status Of Amerika

Mahyuddin, 2001, Kuliah Akhlak Tasawuf, Jakarta: Kalam Mulia,

Suryanto, 2011. Pembelajaran Kontektual Dalam Membangun Karakter Siswa. Jakarta: Direktorat Jendral Pendidikan Dasar

Samani Muchlas dan Hariyanto. 2012. Konsep dan Model Pendidikan Karakter. Bandung: Remaja Rosdakarya 
Read, Herbert. 1990. Pengertian Seni. Diterjemahkan Oleh Soedarso SP. Yokyakarta: Suka Dongar Sona

Poerwadarminta, 2005. Kamus Besar Bahasa Indonesia. Jakarta: Balai Pustaka Mulyana. 2004. Metode Penelitian Kualitatif. Bandung: Alfabeta.

Santoso, Sugeng. 2011. Konsep Pendidikan Anak Usia Dini. Jakarta: Universitas Negeri Padang 


\title{
CHARACTER OF CHILDREN DISCIPLINE IN LEARNING DRAWING
}

\author{
Farida Mayar \\ Lecturer of Teacher Education Early Childhood Education \\ Faculty of Science Education \\ State University of Padang \\ Email: mayarfarida@gmail.com
}

\begin{abstract}
Drawing lesson in Kindergarten. Type of qualitative research using observation, interview. Recording, and shooting. This is done to examine the information data that is closely related to the character of the discipline of drawing learning activities, and the drawing of the child.

The results of the research can be known teacher membelajarkan child about the character of discipline begins religious values, with the theme of self, all the senses are told to the child like the five senses done in accordance with the provisions of religion such as starting the right hand to do good as a child to distribute books Drawing to his friends, means here the teacher teaches children about discipline through the right hand. Furthermore, in drawing a child does not imitate the image of his friend, of all the results of images made different children, in accordance with ideas, ideas and imagination of each child. About the color drawing crayons are not out of line, the image is clean, and neat. The next child appears to the front of the class to tell the results of the picture, ending with the mother of the teacher tells about the behavior of children during the learning process in order to correct the discipline during the learning drawing took place the results of all discipline children.
\end{abstract}

\section{Keywords: Character, Discipline, Drawing}

\section{Preliminary}

Educate according to its potential is very important. Because conformity in educating children affect future developments. The principle of learning to play while learning while playing, which is used to educate students in the development of cultural arts and character of the nation to get the students to recognize and accept the values of art and culture and character of the nation as a common property. Children Kindergarten in general do not know what is good and bad for them. Therefore, educators need to imitate and guide in a good direction like character education

Puskur in Suryanto (2011) stated that 18 identifiable characters originating from religion, pancasila, culture, and national education goals are religious, 
honest, tolerance, discipline, hard work, creative, independent, democracy, curiosity, spirit, nationality, Love the homeland, appreciate achievement, friendly / communicative, love peace, love to read, care environment, social care, and responsibility.

Kindergarten children likened to sprouts that will quickly develop, so that in kindergarten is a golden period, every child is playing the first stone of educational foundation, so that children of optimal kindergarten to absorb science. Character of kindergarten children in the activities and the results of the drawings he made written in accordance with what he expressed.

Every student in drawing generally devotes what is in the depths of the heart expressed through the paper, this is certainly without the personal character of the protege. Characters in drawing need not be searched, because the character will be born alone, and will grow by itself. Gil (1996) beauty in art has a close relationship with the human ability in expression and assess the artwork concerned or associated with the pattern of view and experience of individuals in the creativity.

Purwanto (1997) states that character is a human inner structure that looks at the behavior and actions that are characteristic of the person concerned. Jung (2003) every type of human personality accentuates a process of character or characteristic that affects widely human behavior. In that pattern he says that man has two orientations or a basic tendency in channeling his attention and all his abilities. The tendency to direct and channel outgoing attention is called extrovert. Conversely, the tendency to direct and channel attention into oneself is called introvert.

The formation of character and character or personality is very important (Suryanto 2011). In the meantime, Puskur in Suryanto (2011) stated that 18 identifiable characters originating from religion, pancasila, culture, and national education goals are religious, honest, tolerance, discipline, hard work, creative, independent, democracy, curiosity , Spirit, nationality, love of the homeland, respect for achievement, friendship / communicative, peace loving, reading, caring environment, social caring, and responsibility. 
Samani (2012) character is the basic value that builds one's personal, formed both because of the influence of heredity and the influence of the environment that distinguishes with others, and is manifested in the attitude and behavior in everyday life. Daryusti (2011) states that studying the character of things can not be separated from the aesthetic norms embodied in the embodiment. Kostelametz (1978) says that aesthetics is another word of art philosophy, the abstract mind that gives understanding to the artistic experience in general to gain comprehensive relevance. Related to that, Read (1990) says that beauty can be defined as something fun. On the other hand, Gil (1976) states that beauty in art has a close relationship with the human ability in assessing the work of art concerned to appreciate the beauty. Therefore it should be realized that a beauty will not be separated or strongly associated with the religious view of a person because the life of art with religion as if it has continuity of the realization of artwork. This linkage appears in the activities that arise in the appreciation of the art work in harmony with the religion that is interwoven into a harmonious unity.

From the explanation above, the relationship of character with art is very close with the character will create beautiful artwork that reflects the culture of the nation. In eighteen characters in education one of which is disclosed is discipline, because discipline is very important in everyday life, especially in drawing education.

Among the noble teachings deeply emphasized in Islam is discipline. Such as doing the prayers five times a day overnight in a timely manner. Discipline is one of the doors to success. Expertise in the field of science will have no significant meaning without discipline. Often we meet high knowledgeable people but not able to do much with his knowledge, because of lack of discipline.

On the contrary, many people whose level of knowledge is mediocre but actually achieve tremendous success, because the very discipline in his life is like a religion without blind science, very discipline in his life is like a religion without blind science, science without religion paralyzed. The analogy is simple, we can see the importance of the rule in drawing children taught that in drawing 
coloring should not be out of line. Then return the ingredients and drawing tools placed in place. The above example can certainly be drawn into the realm of the wider life. Strictly speaking, discipline is strongly emphasized in the affairs of the world, and moreover the matter of the afterlife. No wonder God orders the believers to get used to discipline. The command, among others, is implicit in the Qur'an of Surat al-Jumuah, verses 9-10.

No educational institution does not teach discipline to its students. Similarly any organization or institution, more so military, must be very stressed discipline to every party involved in it. All must agree, any great plan will fail in the middle of the road when not supported by discipline. According to Kamus Besar Bahasa Indonesia (KBBI), discipline is obedience or compliance with the rules. Obedience means the willingness of the heart to sincerely fulfill every rule that has been made and agreed upon. Living people are not for rules, but everyone needs rules to make life easy for him.

Nowadays, the attitude of discipline is being abandoned by some of our society. They consider discipline to be a mere discourse without them running. Discipline is the same as obeying the rules / regulations. In Indonesia, many Indonesian people are not obedient to the rules / rules that they make their own eg the existence of the rules in the school but still much violated, the sidewalks used as business street seller, civil servants who come home from work not in time, in the community of course There are rules of norm, although the rules are either written or unwritten and so forth. rules of norm, although the rules are either written or unwritten and so forth.

Basically every rule is binding and has goals to be achieved within the members in it. When there are members in it obeying the rules, then he can be called to have carried out the attitude of discipline and if doing otherwise will get sanction. Actually, to be disciplined is easy if we do gradually will turn into a habit.

From these habits will trigger us to behave in accordance with existing regulations. However, today our society is now accustoming to the opposite habit of discipline. Our society seems apathetic to the attitude of discipline that they 
actually know what is the meaning of discipline. They consider his attitude far from the word/meaning of discipline is something reasonable and understandable. It is so that makes the performance of our society is not optimal and also cause various other problems. To cultivate the attitude of discipline in society today is very important to make a good society life order. As for several ways to foster a culture of discipline in society, among others, change the mindset of society about discipline, planting discipline attitude early on. The existence of strict sanctions for violators, socialization-socialization about the meaning of discipline and so forth.

Discipline is a process of learning to develop habits, self-control and confess personal responsibility to society and the existing rules, then try to be disciplined because discipline is our responsibility.

In the above explanation it is necessary to discipline since early childhood especially in drawing activities. Early childhood is a golden age for children. This golden age has significance and value because it is the foundation for the future of the child. This child's time has the freedom to express without any rules that block and limit it. Therefore, in the golden age it is necessary for parents, teachers, and the community to provide discipline to children so that children can implement discipline from an early age that will affect the discipline of children in adulthood later.

Poerwadarminta in Big Indonesian Dictionary (2005: 28) interpret the word discipline is the exercise of mind and character with the intention that all the attention of children always obey the order in school. Meanwhile, according to Hurlock (2001) in his book Child Development means the behavior of discipline that is the behavior of someone who learns from or voluntarily follows a pemimipin. In this case the child is a student who learns from adults about life towards a useful and happy life in the future.

From the above understandings it can be concluded that discipline is the order or rules that must be done in everyday life to train the character of existing members in educational institutions. The main point of the discipline is regulation. Discipline on drawing activities such as children sitting in an orderly listening to 
the teacher's story on themes, drawing steps, drawings to be made of children, tools to be taken by children, when drawing, finished drawing them straightening materials and tools and tidying up as before

\section{Research methods}

This research uses qualitative method which is descriptive analysis. The study population was Kindergarten and group B sampler. To find the character of discipline in the activities of the drawing that have been made by the students. Mulyasa (2004) qualitative research aims to gain a determined experience of the experience of the people as perceived by the person concerned. This research is done through three stages of activity, that is. (1) initial activities, (2) core activities, and (3) closing activities. After doing the three stages, the researcher examines the results of drawings made students to reveal the character of the image. This research uses competence-related informants to be able to provide opinions, thoughts, assessments and reinforcements that the researcher of the treatment in the framework of preparing the completion and validate this research. Techniques and data collection tools used in this study using interviews, observation, recording, and shooting. This is done to record data of information related to the character of discipline in drawing activities conducted by kindergarten children. The standard of validity of Guba's (1989) thought, namely: 1) Belief (credibility), 2) transforability, 3) dependability, and 4) affirmation or confirmability.

\section{Results and Discussion}

Discussion of research results conducted by synchronize the results of research with the concepts and theories that have been put forward. According to Bogdan and Biklen (1982) said the theme is a concept or theory arising from the results of research. The results of data interpretation research are formulated into the form of themes and research topics.

In the early activities of the picture we can see the disciplinary child of the character regelius love God Almighty. For the values of the character of love to God Almighty kindergarten teachers have implemented it began to come to 
kindergarten children shake hands with teachers mother by saying assamualuaikum, then continued at the morning ceremony, go to class, as well as reading short verses. In the core of the core also children read bismilahhirahmanirrahhim before work and explained about the power of God Almighty, like self by itself. The teacher tells the story and asks who created us, seen some children raised from the number of children raising the hands of the teacher chooses one of them while the other friend does not have a fuss and feel jealous, his friend replied "Allah" all disciplined listen to the answer from his friend after It's teacher and kid applause with joy. Continued the teacher started telling the story about the theme, for the activity of drawing the child heard with discipline pay attention to the explanation of the teacher, the teacher praised the discipline and discipline of his son by applauding everything.

Furthermore, the teacher explained about drawing, the child takes the picture book in the field no one is fighting over the teacher to teach the child that is appointing three children to take the picture book forward and share the picture book to his friends with the pleasure of receiving the drawing book, that way the teacher to share the picture book is not fighting over things These results keep the child from making a fuss when picking up a picture book. Similarly, crayons are in the Kid's kindergarten lockers pointing among them three people to hand out crayons to their friends orderly so that discipline is maintained. The meaning taken from the discipline is the teacher teaches the child in a way there is a social soul sharing the task to socialize on his friend. Teachers as early childhood educators to instill moral and religious values in accordance with the opinion of Mahyuddin (2011) states Educate children discipline from small to follow the call of Allah SWT and leave all its prohibition, educate children from small noble character.

As children take materials and tools to draw in the set in such a way each locker with no queue to take a picture book because it was sent to share the picture book to their friends with discipline and so did not wrestle then the friend who was sent to go to sit friend who has provided. When they are drawing kindergartners do not imitate the image of their friends, they make their own 
according to their ideas and ideas, imagination and creativity. From the above explanation that the child has carried out the character of discipline, take time to draw implemented by the child in accordance with applicable provisions.

Pictures that children make with their freedom to be disciplined, in this case is the children make a picture with their own ideas like a child make a picture of his own hands and then given a decoration of a ring attached to the ring finger with spontaneous, and others . The researcher rewards the child that the picture is good. Researchers interviewed this child why the hand drawing was made. This child replied that the word mother of the hand teacher is God's creation is useful for doing fine work, such as to write, eat and pray, and I come to school always greeted with greeting also with mother's aroma teacher again. There are children who make pictures bungga, junk images, floods, and so forth. In this case, the researcher was moved to hear the conversation from the child that he had known that God created the human hand should we appreciate when the researcher thrust his thumbs while praising the good picture, seen on his face feeling happy. So the image made by the child is not a cheat sheet of his friend image but is his own creation, meaning that the child has disciplined himself. The meaning taken from the child is from a small already accustomed discipline has become a common thing that we need to develop for the future of the nation. The success of education, depends on the educator of an early age. Before entering elementary school children should be given the right education and discipline, meaning the influence in accordance with its development (Santoso, 2011).

At the end of the learning process closed by giving apsresiasi to children which means ranging from summarizing the discipline of children in learning to draw to the results of children's drawings. As in the child's discipline in the learning activities of drawing the teacher praised all the children's attitude from his behavior began hearing from the story of the teacher, with the theme of disciplined duck, which is essentially duck in the morning to go foraging along with regularity running always one march lengthwise no first And do not scramble in his journey to the fields, in the afternoon duck back home was so always regular, seen all the ducks are very disciplined in doing the work he always play 
in the water does not disturb human. From the above explanation the teacher gave an example that animals are only disciplined life. How about mother's child. Well, you see the mother of discipline is not all that good fight. Let's applause everything, pick up a picture book and crayon a motherly child orderly pick it up with three people who distributed the picture book to friends all everything goes in an orderly manner, about the picture made by the child, the image the child made in accordance with the ideas and ideas of each There is the same. Everything goes orderly and disciplined.

\section{Conclusion}

Based on the results of research and discussion can be put forward several things related to the character of child discipline in the picture in kindergarten. Teachers teach children the character of discipline begins religious values, starting from the theme of self, all the senses are told to the child. Furthermore the senses are done in accordance with the provisions of religion as it begins the right hand to do a good job as the child distributes a picture book to his friend. This means that the teacher teaches children about discipline through hands, then in drawing a child does not imitate his friend's drawing, of all the drawings made by different children, in accordance with the ideas, gagsan and imagination of the child. Crafting color crayons are not out of line, the results are clean, then the child comes forward to tell the drawing result, ends with the teacher's mother telling about the behavior of the child during the learning process takes place the discipline also to the child the results of all discipline.

\section{References}

Al-Qur'an Surah Al-Jumuah, verses 9-10. Bandung: CV Dipenogoro

Bogdan, R.C, Biklen, SK. 1982. Qualitative Research for Education: An Introduction to Thory Edition Methods. Boston: Allyn and Bacon Charmaz.

Daryusti. 2011. Hegemony Penghulu In Cultural Perpektif (Revised Edition) Yogyakarta: CiptaMedia.

Gil. 2011. Picking Beauty In Art. Jakarta: Varia

Guba, E.G. \& Lincoln, Y. S. 1989. Fourt Generation Evaluation. Newbury Park, Ca: Sage.

Hurlock, B Elizabeth. 2001. Child Development. Volume 1. Jakarta: Erlanga. 
Kostelamet. Z. Richard (ed) 1978. Estethics Contenporary, New York: Status Of America.

Mahyuddin, 2001. Lecture of Moralism, Jakarta: Kalam Mulia

Suryanto, 2011. Contextual Learning In Building Student Character. Jakarta: Directorate General of Primary Education.

Samani Muchlas and Hariyanto. 2012. The Concept and Model of Character Education. Bandung: Teens Rosdakarya

Read, Herbert. 1990. Understanding Art. Translated by Soedarso SP. Yokyakarta: Sau Dongar Sona

Poerwadarminta, 2005. Big Indonesian Dictionary. Jakarta: Balai Pustaka

Mulyana. 2004. Qualitative Research Methods. Bandung: Alfabeta.

Santoso, Sugeng. 2011. The concept of Early Childhood Education. Jakarta: State University of Jakarta 
